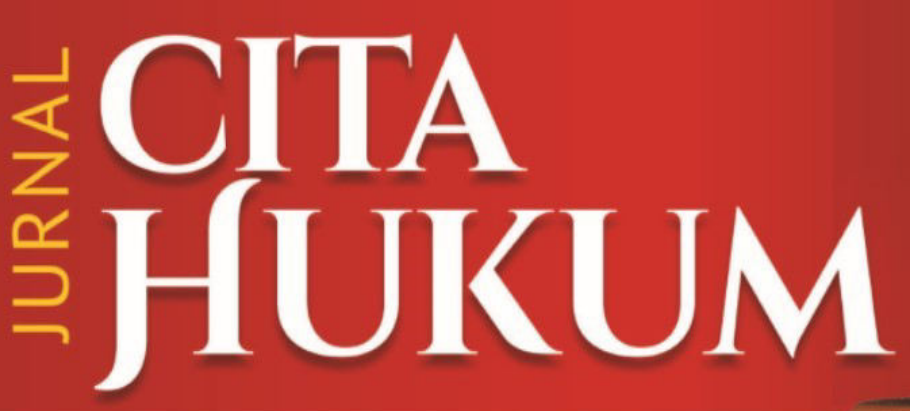

Indonesian Law Journal

- Related with Judicial Conditions in The Civil Case Evidence in The Court (Case Study of Decision No. 47 / Pdt.G / 2012 / PN Lsk and Decision No. 16/Pdt.G/2012/PN Stb)

Efa Laela Fakhriah \& Yustika Tatar Fauzi Harahap

- Model Setting of Political Party System and Electoral Systems to Prevent Political Corruption Agus Riwanto \& Achmad

- A Patient's Legal Protection as a Victim of Sexual Harassment on Medical Services in Indonesia

Siska Elvandari \& Mey Lin Chan

- Filling the Position of Constitutional Court Judge and Its Correlation with the Independence of Judges (Comparative Study of Some Countries)

M. Beni Kurniawan

- The Institutional Renewal in Settlement of Disputes of Local Election Results Heru Widodo

- The Rebellion Indication Towards Sovereign Government in Acts of Terrorism in Indonesia In Transcendental Dimension

Irfan Hielmy \& Nur Rohim Yunus

- Politik Hukum Dalam Kebijakan Hukum Pidana LGBT

Iqbal Kamalludin, Hirda Rahma, Aldila Arumita Sari \& Pujïyono

- Pengaruh Konvensi Hukum Laut Internasional Tahun 1982 Terhadap Wilayah Laut Indonesia Yoyon Mulyana Darusman

- Pengawasan Pengurus Ikatan Notaris Indonesia Kota Padang Terhadap Pelaku Pelanggaran Kode Etik

Nisaul Hasanah, Azmi Fendri \& Neneng Oktarina

Volume 6 Number 2 (2018) 


\section{Jurnal}

\section{CITA HUKUM}

\section{VOLUME 6 NUMBER 2 (2018)}

CITA HUKUM is Indonesian Law Journal published by Faculty of Sharia and Law, State Islamic University Syarif Hidayatullah Jakarta in Associate with Center for Study of Indonesian Constitution and Legislation (POSKO-LEGNAS) UIN Jakarta.

This journal specializes in Indonesian Legal Studies and try to present various results of the latest and high-quality scientific research which is issued twice in a year at June and December.

CITA HUKUM has been indexed at DOAJ, EBSCO, Microsoft Academic Search, Emerging Source Citation Index (ESCI) Clarivate Analytics, and SINTA 3 and become a CrossRef Member since year 2015.

Therefore, all articles published by CITA HUKUM will have unique DOI number.

\section{INTERNATIONAL ADVISORY BOARD}

Prof. Tim Lindsey, SCOPUS ID: 36785442900; h-index: 5, Melbourne University Australia

Prof. Muhammad Munir, Scopus ID: $54414595100 \mathrm{~h}$-index: 1, Department of Law, International Islamic University Islamabad, Pakistan Prof Mark Cammack, Scopus ID: $6507998992 \mathrm{~h}$-index: 3, Southwestern Law School Los Angeles USA

Prof. Euis Nurlaelawati, Scopus ID: 56247081700 h-index: 1, Faculty of Sharia and Law, UIN Sunan Kalijaga Yogyakarta

\section{EDITORIAL BOARD}

Prof. Gani Abdullah, h-index Google Scholar: 5, UIN Syarif Hidayatullah Jakarta

Prof. Salman Maggalatung, h-index Google Scholar: 3, UIN Syarif Hidayatullah Jakarta

Dr. Asep Saepudin Jahar, Scopus ID: 57156653300, h-Index Google Scholar: 1, UIN Syarif Hidayatullah Jakarta

Dr. Ahmad Tholabi Kharlie, Thomson Reuters Id: R-5028-2017, h-Index Google Scholar: 3, UIN Syarif Hidayatullah Jakarta

\section{EDITOR IN CHIEF}

Nur Rohim Yunus, Thomson Reuters Researcher ID: F-3477-2017, ORCID ID: 0000-0003-27821266, SSRN ID: 2645355, h-index Google Scholar: 4, Department of Constitutional Law, UIN Syarif Hidayatullah Jakarta, Indonesia

\section{MANAGING EDITOR}

Muhammad Ishar Helmi, Thomson Reuters Researcher ID: F-3345-2017, ORCID ID: 0000-0001-7060-8191, h-index Google Scholar: 2, Department of Criminal Law UIN Syarif Hidayatullah Jakarta, Indonesia

\section{EDITORS}

Indra Rahmatullah, ORCID ID: 0000-0002-6160-4225, h-index Google Scholar: 2, Department of Economic Law, Faculty of Sharia and Law, UIN Syarif Hidayatullah Jakarta, Indonesia.

Mara Sutan Rambe, ORCID ID: 0000-0001-5404-6635, h-index Google Scholar: 1, Department Criminal Law, Faculty of Law, UIN Syarif Hidayatullah Jakarta, Indonesia.

\section{ENGLISH LANGUAGE EDITOR}

Fitria, ORCID ID: 0000-0001-9733-1233, Department of International Law, York Law School, University of York, UK, United Kingdom.

\section{ASSISTANT TO THE EDITORS}

Erwin Hikmatiar, Thomson Reuters Researcher ID: F-3235-2017, ORCID ID: 0000-0003-4103-818X, UIN Syarif Hidayatullah Jakarta

\section{Redaktur Office}

Faculty of Sharia and Law UIN Syarif Hidayatullah Jakarta

Street Ir. H. Juanda 95 Ciputat Jakarta 15412

Phone. (62-21) 74711537, Faks. (62-21) 7491821

Website: www.fsh-uinjkt.net, E-mail: jurnal.citahukum@uinjkt.ac.id

Link: http://journal.uinjkt.ac.id/index.php/citahukum 


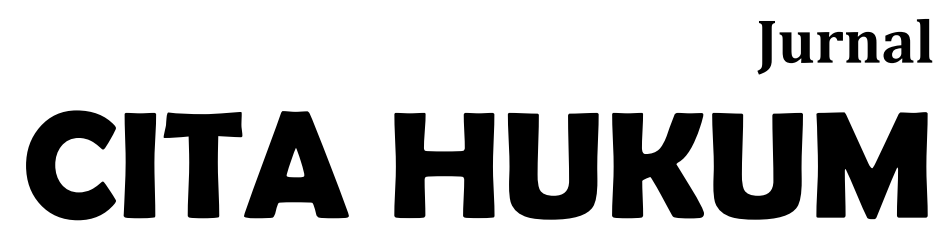

INDONESIAN LAW JOURNAL

Welcoming contributions from scientists, scholars, professionals, and researchers in the legal disciplines to be published and disseminated after going through script selection mechanisms, reviewing sustainable partners, and rigorous editing processes. 


\section{TABLE OF CONTENTS}

Related with Judicial Conditions in The Civil Case Evidence in The Court (Case Study of Decision No. 47 / Pdt.G / 2012 / PN Lsk and Decision No. 16/Pdt.G/2012/PN Stb)

Efa Laela Fakhriah, Yustika Tatar Fauzi Harahap 201-216

Model Setting of Political Party System and Electoral Systems to Prevent Political Corruption

Agus Riwanto, Achmad $217-234$

A Patient's Legal Protection as a Victim of Sexual Harassment on Medical Services in Indonesia

Siska Elvandari, Mey Lin Chan.

$235-252$

Filling the Position of Constitutional Court Judge and Its Correlation with the Independence of Judges (Comparative Study of Some Countries)

M. Beni Kurniawan. 253-276

The Institutional Renewal in Settlement of Disputes of Local Election Results Heru Widodo 277-292

The Rebellion Indication Towards Sovereign Government in Acts of Terrorism in Indonesia In Transcendental Dimension

Irfan Hielmy, Nur Rohim Yunus 293-316

Politik Hukum Dalam Kebijakan Hukum Pidana LGBT (Legal Politics in the LGBT Criminal Law Policy)

Iqbal Kamalludin, Hirda Rahma, Aldila Arumita Sari, Pujiyono $317-342$

Pengaruh Konvensi Hukum Laut Internasional Tahun 1982 Terhadap Wilayah Laut Indonesia (The Influence of the 1982 International Convention on the Law of the Sea against the Indonesian Ocean Territory)

Yoyon Mulyana Darusman $343-360$

Pengawasan Pengurus Ikatan Notaris Indonesia Kota Padang Terhadap Pelaku Pelanggaran Kode Etik (Supervision of the Management of the Indonesian Notary Association in Padang City Against Perpetrators of the Code of Ethics)

Nisaul Hasanah, Azmi Fendri, Neneng Oktarina 361-386 



\title{
Pengawasan Pengurus Ikatan Notaris Indonesia Kota Padang Terhadap Pelaku Pelanggaran Kode Etik*
}

\author{
(Supervision of the Management of the Indonesian \\ Notary Association in Padang City Against \\ Perpetrators of the Code of Ethics)
}

\author{
Nisaul Hasanah, ${ }^{1}$ Azmi Fendri, ${ }^{2}$ Neneng Oktarina ${ }^{3}$ \\ Magister Kenotariatan Universitas Andalas, Padang, Indonesia
}

DOI: $10.15408 /$ jch.v6i2.8642

\begin{abstract}
.
Notary is a profession that demands office holders and the profession has scientific competence and moral competence. Based on the code of ethics, the results of the changes are interesting to see the supervision and enforcement of a code of ethics for notaries who violate the code of ethics by the board of the Indonesian Notary Association (INI). Supervision and enforcement of a notary code of ethics by the Management of the Indonesian Notary Association in the city of Padang is carried out by the Regional Honorary Council. Supervision and enforcement of the code of ethics is carried out in a multilevel manner, if a suspected violation of the code of ethics is not satisfied with the decision of the regional or regional council of honor, then an appeal can be made against the Central Honorary Council. If it has not been satisfied with the decision of the Central Honorary Board, it can be appealed to Congress. While legal issues that arise related to supervision of a Notary who violates the code of ethics by the Management of the Indonesian Notary Association in the City of Padang, namely the inadequacy of rules related to the notary examination event by the Honorary Board of the Notary Association of Indonesian Notaries.
\end{abstract}

Keywords: Supervision, Violation, Code of Ethics

${ }^{*}$ Received: July 6, 2018, revised: August 10, 2018, Accepted: November 21, 2018.

${ }^{1}$ Nisaul Hasanah adalah Peneliti pada Program Magister Kenotariatan, Fakultas Hukum Universitas Andalas, Padang, Sumatera Barat, Indonesia. E-mail: nisaulhasanah480@gmail.com.

${ }^{2}$ Azmi Fendri adalah Peneliti pada Program Magister Kenotariatan, Fakultas Hukum Universitas Andalas, Padang, Sumatera Barat, Indonesia. E-mail: azmi26@gmail.com.

${ }^{3}$ Neneng Oktarina adalah Peneliti pada Program Magister Kenotariatan, Fakultas Hukum Universitas Andalas, Padang, Sumatera Barat, Indonesia. Email: nenengfh@gamail.com. 


\title{
Pengawasan Pengurus Ikatan Notaris Indonesia Kota Padang Terhadap Pelaku Pelanggaran Kode Etik
}

\begin{abstract}
Abstrak.
Notaris merupakan sebuah profesi yang menuntut pemangku jabatan dan profesi tersebut memiliki kompetensi keilmuan dan kompetensi moral. Berdasarkan kode etik hasil perubahan terlihat pengawasan dan penegakan kode etik terhadap notaris yang melakukan pelanggaran kode etik oleh pengurus Ikatan Notaris Indonesia (INI). Pengawasan dan penegakan kode etik notaris oleh Pengurus Ikatan Notaris Indonesia kota Padang dilaksanakan oleh Dewan Kehormatan Daerah. Pengawasan dan penegakan kode etik dilaksanakan secara bertingkat. Apabila terduga pelanggaran kode etik tidak puas dengan keputusan dewan kehormatan daerah, maupun wilayah, maka dapat mengajukan banding terhadap Dewan Kehormatan Pusat. Jika belum terpuaskan dengan putusan Dewan Kehormatan Pusat, maka bisa diajukan banding ke Kongres. Permasalahan hukum yang timbul terkait pengawasan terhadap Notaris yang melakukan pelanggaran kode etik oleh Pengurus Ikatan Notaris Indonesia di Kota Padang yaitu belum memadainya aturan-aturan terkait acara pemeriksaan notaris oleh Dewan Kehormatan Notaris Ikatan Notaris Indonesia.
\end{abstract}

Kata Kunci: Pengawasan, Pelanggaran, Kode Etik

\section{Recommended Citation:}

Hasanah, Nisaul, Fendri, Azmi, and Oktarina, Neneng. "Pengawasan Pengurus Ikatan Notaris Indonesia Kota Padang Terhadap Pelaku Pelanggaran Kode Etik" JURNAL CITA HUKUM [Online], Volume 6 Number 2 (2018). 


\section{Pendahuluan}

Pada poin C konsideran Undang-Undang Nomor 30 Tahun 2004 tentang Jabatan Notaris sebagaimana diubah dengan Undang-Undang Nomor 4 Tahun 2014 (selanjutnya disebut UUJN). Dijelaskan bahwa notaris merupakan jabatan tertentu yang menjalankan profesi dalam pelayanan hukum kepada masyarakat, perlu mendapatkan perlindungan dan jaminan demi tercapainya kepastian hukum. Pada konsideran tersebut secara jelas Notaris disebutkan sebagai sebuah profesi. A.S Moenir juga mendefinisikan profesi sebagai aktivitas intelektual yang dipelajari termasuk pelatihan yang diselenggarakan secara formal ataupun tidak formal dan memperoleh sertifikat yang dikeluarkan oleh sekelompok/badan yang bertanggung jawab pada keilmuan tersebut dalam melayani masyarakat, menggunakan etika layanan profesi dengan mengimplikasikan kompetensi mencetuskan ide, kewenangan keterampilan teknis dan moral. ${ }^{4}$

Dari definisi profesi seperti yang dijelaskan A.S Moenir tersebut, maka dapat mengangkat dua elemen penting dalam menjalankan profesi, yang pertama merupakan elemen kompetensi keilmuan dan yang kedua adalah elemen kompetensi moral. Kompetensi keilmuan ini bisa diartikan sebagai suatu keahlian teknis seseorang terkait profesinya sehingga dapat menjalankan segala aktifitas profesi secara professional, kompetensi ini yang membuat seseorang pantas untuk menduduki profesi tersebut. Namun, selain keahlian teknis tersebut, sebuah profesi juga harus memiliki kopetensi lain yang tidak dapat dipisahkan dari kompetensi keilmuan atau kompetensi teknis ini, kompetensi tersebut adalah kompetensi moral. Kompetensi moral berkaitan dengan penilaian terhadap perbuatan manusia dan dijadikan standar yang bersifat etik yang digunakan untuk membedakan perbuatan-perbuatan manusia mengenai nilai-nilai dan norma-norma etis yang bersifat susila dan harus ditunjang oleh integritas moral yang tinggi. ${ }^{5}$

Kaitannya dengan uraian diatas adalah secara ideal, Notaris sebagai sebuah jabatan dan profesi harus juga memenuhi kedua elemen tersebut, baik kompetensi teknis dan kompetensi moral. Jika salah satunya tidak dimiliki oleh seseorang, maka dia tidak bisa untuk menduduki jabatan dan profesi notaris. Pada Pasal 3 Undang-Undang-Undang Nomor 4 Tahun 2014 Tentang Perubahan Undang Nomor 30 Tahun 2004 tentang Jabatan Notaris, seorang notaris memiliki persyaratan sebagai berikut: 1). Warga negara Indonesia; 2).

\footnotetext{
${ }^{4}$ Moenir, Manajemen Pelayanan Umum di Indonesia, (Jakarta: PT. Bumi Aksara, 2002), h.63.

${ }_{5}^{5}$ Pengurus Pusat Ikatan Notaris Indonesia, Jati Diri Notaris Indonesia Dulu. Sekarang dan Di Masa Datang, (Jakarta: Gramedia Pustaka, 2008), h.194.
} 
Bertakwa kepada Tuhan Yang Maha Esa; 3). Berumur paling sedikit 27 (dua puluh tujuh) tahun; 4). sehat jasmani dan rohani yang dinyatakan dengan surat keterangan sehat dari dokter dan psikiater; 5). Berijazah sarjana hukum dan lulusan jenjang strata dua kenotariatan; 6). Telah menjalani magang atau nyatanyata telah bekerja sebagai karyawan Notaris dalam waktu paling singkat 24 (dua puluh empat) bulan berturut-turut pada kantor Notaris atas prakarsa sendiri atau atas rekomendasi Organisasi Notaris setelah lulus strata dua kenotariatan; 7). Tidak berstatus sebagai pegawai negeri, pejabat negara, advokat, atau tidak sedang memangku jabatan lain yang oleh undang-undang dilarang untuk dirangkap dengan jabatan Notaris; dan 8). Tidak pernah dijatuhi pidana penjara berdasarkan putusan pengadilan yang telah memperoleh kekuatan hukum tetap karena melakukan tindak pidana yang diancam dengan pidana penjara 5 (lima) tahun atau lebih."

Persyaratan tersebut dapat diklasifikasikan menjadi 2 (dua), yaitu Pertama, persyaratan untuk pencapaian kompetensi teknis/keilmuan; Kedua, kompetensi pencapaian kompetensi moral.

Persyaratan menjadi notaris seperti sehat jasmani yang dinyatakan dengan surat keterangan sehat dari dokter, berijazah sarjana hukum dan lulusan jenjang strata dua kenotariatan, telah menjalani magang atau nyatanyata telah bekerja sebagai karyawan Notaris dalam waktu paling singkat 24 (dua puluh empat) bulan berturut-turut pada kantor Notaris atas prakarsa sendiri atau atas rekomendasi Organisasi Notaris setelah lulus strata dua kenotariatan adalah persyaratan-persyaratan yang tujuannya untuk mengklasifikasikan calon-calon notaris yang berkompeten secara teknis keilmuan profesinya.

Persyaratan bertakwa kepada Tuhan Yang Maha Esa, berumur paling sedikit 27 (dua puluh tujuh) tahun, sehat rohani yang dinyatakan dengan surat keterangan sehat dari psikiater, tidak berstatus sebagai pegawai negeri, pejabat negara, advokat, atau tidak sedang memangku jabatan lain yang oleh UndangUndang dilarang untuk dirangkap dengan jabatan Notaris; dan tidak pernah dijatuhi pidana penjara berdasarkan putusan pengadilan yang telah memperoleh kekuatan hukum tetap karena melakukan tindak pidana yang diancam dengan pidana penjara 5 (lima) tahun atau lebih adalah persyaratanpersyaratan pencapaian kompetensi moral bagi seorang notaris.

Pada dasarnya kompetensi moral bersifat lebih abstrak karena berkaitan dengan personal seseorang, sedangkan kompetensi keilmuan lebih mudah untuk dicapai karena standarnya jelas. Oleh sebab itu, kajian mengenai pencapaian kompetensi moral menjadi suatu hal yang lebih menarik. Dalam hal 
jabatan notaris, ketentuan Pasal 3 UUJN tersebut merupakan sebuah langkah awal dalam pencapaian kompetensi moral, masih banyak rentetan aturan yang bertujuan untuk mengawal moral dari pemangku jabatan notaris ini. Salah satunya dengan membentuk kode etik profesi notaris.

Kode etik merupakan sebuah etik yang dikodifikasi supaya dapat dijadikan standar dan pedoman dalam bersikap pada suatu kelompok tertentu. Kode Etik dapat digambarkan sebagai aturan-aturan moral terkait dengan suatu profesi, pekerjaan, atau jabatan tertentu yang mengikat dan membimbing para anggotanya mengenai nilai-nilai baik dan buruk, benar dan salah dalam wadah-wadah organisasi bersama. ${ }^{6}$ Keberadaan kode etik merupakan bentuk kesadaran dari manusia pada lingkungan maupun kelompok tertentu tentang pentingnya etika dalam menjalankan profesi tertentu. Tanpa adanya etika, manusia tidak akan menjadi mahluk mulia yang memberi keberkatan pada seluruh alam. ${ }^{7}$ Kesadaran akan pentingnya etika pada sebuah profesi juga didasari atas pandangan bahwa etika akan menuntun seseorang untuk dapat membedakan yang baik dan yang buruk, sehingga selalu mengutamakan kejujuran dan kebenaran dalam menjalankan jabatannya. Oleh karena itu di dalam menjalankan karyanya wajib didukung oleh Etika Profesi sebagai dasar moralitas. ${ }^{8}$

Dari uraian di atas dapat dipahami mengapa setiap kelompok ataupun profesi selalu mempersiapkan kode etik bagi anggota kelompoknya, tidak terkecuali bagi profesi notaris. Terkait dengan keberadaan kode etik notaris ini dapat kita lihat di dalam Pasal 83 angka (1) UUJN dimana dijelaskan bahwa organisasi notaris menetapkan dan menegakkan kode etik notaris. Dari ketentuan tersebut ada dua hal yang dijelaskan yaitu Pertama, terdapat suatu wadah perkumpulan notaris; dan Kedua, organisasi tersebut memiliki kewenangan untuk membentuk dan menetapkan kode etik, serta berkewenangan melaksanakan penegakan kode etik tersebut.

Selanjutnya penjelasan mengenai organisasi notaris tersebut diatur di dalam Pasal 1 angka 5 UUJN yang menyebutkan bahwa Organisasi Notaris adalah organisasi profesi jabatan Notaris yang berbentuk perkumpulan berbadan hukum. Tidak hanya itu, organisasi profesi notaris ini juga telah

6Jimly Asshiddiqie, Peradilan Etik Dan Etika Konstitusi, (Jakarta: Sinar Grafika, 2014), h.103.

7 Pengurus Pusat Ikatan Notaris Indonesia, Jati Diri Notaris Indonesia Dulu. Sekarang dan Di Masa Datang, h.193.

8 Ignatius Ridwan Widyadharma, Etika Profesi Hukum, (Semarang: Badan Penerbit Universitas Diponegoro), 1996, h.15. 
ditentukan oleh UUJN yaitu Ikatan Notaris Indonesia (INI) dan menjadi satusatunya wadah profesi notaris yang bebas dan mandiri. ${ }^{9}$

Kewenangan untuk menetapkan kode etik, Ikatan Notaris Indonesia (INI) setidaknya telah melakukan beberapa kali kongres yang berkaitan dengan kode etik. Kode etik notaris tersebut telah mengalami beberapa kali perubahan yang dilaksanakan melalui kongkres Ikatan Notaris Indonesia. Konggres INI pertama diadakan di Surabaya Tahun 1974 dan kemudian diubah dan disusun kembali dalam Konggres XIII yang diadakan tahun 1981 di Bandung. Tanggal 29 Januari 2005 Kode Etik Notaris di ubah lagi melalui Konggres Luar Biasa Ikatan Notaris Indonesia (INI) di. Sampai saat ini, kode etik yang diberlakukan adalah kode etik hasil kongres Ikatan Notaris Indonesia (INI) yang dilaksanakan 29 Mei sampai 31 Mei 2015 di Banten.

Pada konggres INI yang dilaksanakan di Banten tersebut ada beberapa poin-poin perubahan yang berhasil diinventarisir. Adapun poin-poin perubahan Kode etik Notaris Pasca Kongres Ikatan Notaris Indonesia di Banten pada Tanggal 29-31 Mei 2015 adalah: ${ }^{10} 1$ ). Kewajiban menjalankan jabatan di kantor yaitu pada pasal 3 ayat 15 Kode Etik Notaris menyatakan bahwa notaris wajib menjalankan jabatannya di kantor kecuali dengan alasan-alasan tertentu. Frasa "alasan-alasan tertentu" ini tidaklah memenuhi rumusan yang jelas dan tegas (lex certa) serta ketat (lex stricta). Dengan begitu, maka rumusan ini bisa ditafsirkan berbeda-beda oleh setiap orang; 2). Batasan jumlah akta yaitu pada pasal 3 ayat (18) KEN dijelaskan bahwa notaris wajib membuat akta dalam jumlah batas kewajaran untuk menjalankan peraturan perundang-undangan, khususnya undang-undang tentang Jabatan Notaris dan kode etik notaris. Kemudian didalam Pasal 4 ayat (16) KEN menyatakan bahwa notaris dilarang membuat akta melebihi batas kewajaran yang batas jumlahnya ditentukan oleh dewan kehormatan; 3). Larangan penggunaan media elektronik untuk hal-hal tertentu yaitu pasal 4 ayat 13 KEN mengatur mengenai larangan tidak melakukan kewajiban dan melakukan pelanggaran terhadap larangan menggunakan media elektronik untuk hal-hal tertentu. Hal ini dimaksudkan sebagai peringatan untuk hati-hati dalam menggunakan media elektronik, misalnya terkait promosi ataupun menerbitkan opini dan apalagi terkait temanteman se-profesi; dan 4). Larangan mengikuti pelelangan yaitu pasal 4 ayat (17) KEN diatur mengenai larangan mengikuti pelelangan untuk mendapatkan pekerjaan pembuatan akta. Larangan lelang tersebut khusus terkait pelaksanaan kewenangan notaris, bukan selaku pribadi.

\footnotetext{
9 Pasal 82 UUJN.

${ }_{10}$ Zul Fadli, Membedah Kode Etik Baru, Majalah Renvoi, 3 Januari 2016, Jakarta 2016.
} 
Poin-poin di atas merupakan poin perubahan yang berhasil diinventarisir. Sebenarnya masih banyak poin-poin yang belum dibahas, akan tetapi perubahan ini tentu akan berpengaruh terhadap pengawasan dan penegakan kode etik termasuk pada pengawasan dan penegakan kode etik. Berdasarkan argumen tersebut, maka menarik untuk dibahas mengenai pengawasan terhadap notaris yang melakukan pelanggaran kode etik oleh Pengurus Ikatan Notaris Indonesia Kota Padang pasca perubahan kode etik Notaris hasil Konggres Ikatan Notaris Indonesia di Banten pada Tanggal 29-31 Mei 2015.

\section{Pengawasan dan Penegakan Kode Etik terhadap Notaris yang Melakukan Pelanggaran Kode Etik oleh Pengurus Ikatan Notaris Indonesia Kota Padang}

Anggaran Dasar Ikatan Notaris Indonesia yang telah direvisi pada tahun 2015 di Banten dijelaskan bahwa tujuan dari dibentuknya perkumpulan ataupun organisasi notaris yang dalam hal ini adalah Ikatan Notaris Indonesia adalah untuk menegakan kebenaran dan keadilan serta terpeliharanya keluhuran martabat jabatan Notaris sebagai pejabat umum yang bermutu dalam rangka pengabdiannya kepada Tuhan Yang Maha Esa, Bangsa dan Negara agar terwujudnya kepastian hukum dan terbinanya persatuan dan kesatuan serta kesejahteraan anggotanya. ${ }^{11}$

Salah satu upaya untuk mewujudkan tujuan tersebut adalah dengan menegakan aturan-aturan terkait etika dari notaris itu sendiri. Seperti diketahui bahwa setiap profesi memiliki standar etika yang dituangkan di dalam kode etik. Hal ini berlaku juga bagi notaris dimana notaris dalam menjalankan aktifitas dan kegiatannya sebagai notaris juga harus sesuai dengan standarstandar etika yang tertuang di dalam kode etik. Untuk menjamin efektifitas aturan tersebut guna mencapai tujuannya, maka organ-organ di dalam Ikatan Notaris Indonesia haruslah bersinergi, bersatu, dan bekerjasama, sehingga citacita memelihara keluhuran martabat jabatan Notaris dapat tercapai.

Pasal 10 AD INI hasil KLB Banten 2015 disebutkan bahwa alat kelengkapan organisasi Ikatan Notaris Indonesia (INI) terdiri dari Rapat anggota, Kepengurusan, Dewan Kehormatan dan Mahkamah Perkumpulan. Pada dasarnya organ-organ ini memiliki tugas mewujudkan tujuan dari organisasi yang salah satunya adalah menjaga dan memelihara keluhuran martabat jabatan Notaris. Oleh sebab itu, maka untuk melihat bagaimana

\footnotetext{
${ }^{11}$ Pasal 7 AD INI hasil KLB Banten 2015.
} 
upaya dari Pengurus Ikatan Notaris Indonesia mewujudkan cita-cita tersebut maka haruslah dilihat bagaimana organ-organ ini bekerja.

Salah satu yang perlu dilakukan untuk memelihara keluhuran jabatan notaris adalah dengan melakukan pengawasan sekaligus penegakan kode etik terhadap notaris. Pengawasan dapat diartikan secara sempit dan secara luas. Pengawasan dalam artian sempit yang penulis maksudkan disini adalah bahwa notaris melakukan pengawasan demi upaya pencegahan terhadap pelanggaran kode etik notaris, sedangkan pengawasan secara luas tidak hanya pengawasan dalam rangka pencegahan, namun termasuk di dalamnya upaya-upaya penegakan kode etik, sehingga pengawasan tersebut menjadi suatu kesatuan sistem dalam mewujudkan keluhuran profesi notaris. Pengawasan yang dimaksudkan dalam tulisan ini adalah bentuk pengawasan secara luas yang mencakup upaya pencegahan maupun upaya penegakan hukumnya.

Adapun pada poin ini akan dijelaskan mengenai pengawasan yang dilakukan oleh pengurus Ikatan Notaris Indonesia terhadap notaris yang melakukan pelanggaran kode etik. Oleh sebab itu pengawasan yang diberikan lebih kepada upaya-upaya yang dilakukan oleh Pengurus Ikatan Notaris Indonesia Kota Padang dalam hal telah terjadi pelanggaran ataupun dugaan pelanggaran kode etik yang dilakukan oleh notaris. Perumusan yang demikian penting untuk menganalisis lebih lanjut organ-organ mana saja yang terlibat ketika hal ini terjadi. Jika terdapat dugaan pelanggaran kode etik oleh notaris, maka ada beberapa hal yang dilakukan oleh Pengurus Ikatan Notaris Indonesia kota Padang, penyelidikan, pemeriksaan dan penjatuhan sanksi terhadap notaris yang melakukan pelanggaran kode etik.

Sesuai dengan permasalahan yang dibahas yaitu pengawasan oleh Pengurus Ikatan Notaris Indonesia Kota Padang, maka yang terlibat tentu organ-organ yang ada di dalam pengurus daerah tersebut dan organ kepengurusan Ikatan Notaris Indonesia yang berwenang melakukan pengawasan dan penegakan kode etik terhadap notaris yang melakukan pelanggaran adalah Dewan Kehormatan Notaris atau Dewan Kehormatan Notaris Daerah Kota Padang Ikatan Notaris Indonesia. Hal ini berdasarkan Pasal 7 Kode Etik Notaris yang menyebutkan bahwa pengawasan atas pelaksanaan kode etik dilakukan oleh: Pertama, pada tingkat kabupaten/kota oleh pengurus daerah dan dewan kehormatan daerah; Kedua, pada tingkat provinsi oleh Pengurus wilayah dan dewan kehormatan wilayah; dan, Ketiga, pada tingkat nasional oleh pengurus pusat dan dewan kehormatan pusat.

Namun, yang menjadi pertanyaan adalah ketika seorang notaris diduga telah melanggar kode etik, maka pengurus dan dewan kehormatan 
mana yang akan berwenang memeriksa notaris atau anggota yang bersangkutan, sedangkan seperti diketahui bahwa pemisahan dalam berbagai tingkatan pengurus tersebut hanya bentuk perpanjangan tangan dari kepengurusan secara nasional organisasi Ikatan Notaris Indonesia dan sejatinya anggota yang bersangkutan adalah anggota INI tanpa harus dipisahkan perdaerah ataupun wilayah. Secara nalar seorang notaris dipastikan adalah bagian dari keanggotaan daerah dan juga menjadi anggota wilayah. Namun, jika terjadi permasalahn siapakah yang akan berwenang untuk memeriksa?

Salah satu contoh kasus seorang notaris di Padang Sumatera Barat yaitu Elisa Satria Pilo. Notaris Elisa Satria Pilo ditahan Kejaksaan Negeri Padang bersama mantan Wakil Rektor II Institut Agama Islam Negeri Imam Bonjol (IAIN IB), pada 14 Juli 2016. Kasus itu adalah dugaan korupsi dalam pengadaan tanah kampus III IAIN IB Padang, di Sungai Bangek, Kecamatan Koto Tangah, Kota Padang dengan luas 60 hektar. Terdapat beberapa permasalahan dalam pembebasan tanah itu, di antaranya ada tanah fiktif namun dibayarkan, serta uang ada namun dikerucutkan dari harga yang sebenarnya. ${ }^{12}$ Pengadaan tanah itu diduga kuat mengandung unsur kecurangan yang dapat dikategorikan sebagai sebuah tindak pidana korupsi yang dilakukan secara bersama-sama. ${ }^{13}$

Kasus di atas mencerminkan bagaimana profesi notaris dituntut untuk selalu meningkatkan integritas, kapasitas keilmuan, wawasan umum serta pemahaman terhadap kode etik profesi notaris agar terhindar dari permasalahan-permasalahan hukum dalam rangka menjalankan tugasnya. Saat ini proses hukum dalam kasus Elly Satria Pilo ini telah berjalan. Namun, bagaimana dengan penegakan hukum di bidang etik terhadap kasus tersebut.

Selain itu, pertanyaan lain yang timbul adalah kewenangan dalam pengawasan dan penegakan kode etik oleh Ikatan Notaris Indonesia yang dalam hal ini majelis pengawas daerah juga memiliki kewenangan tersebut. Pada Pasal 70 UUJN dijelaskan bahwa kewenangan Majelis Pengawas Daerah disebutkan antara lain adalah menyelenggarakan sidang untuk memeriksa adanya dugaan pelanggaran Kode Etik Notaris atau pelanggaran pelaksanaan jabatan Notaris serta menerima laporan dari masyarakat mengenai adanya dugaan pelanggaran Kode Etik Notaris atau pelanggaran ketentuan dalam Undang-Undang.

12 http://www.hukumonline.com/berita/baca/lt578f0c854d540/belajar-dari-kasus-iain-ib-notaris-diminta-jaga-profesionalisme, diakses pada 9 April 2018.

13 http://www.hukumonline.com/berita/baca/lt578f0c854d540/belajar-dari-kasus-iain-ib-notaris-diminta-jaga-profesionalisme, diakses pada 9 April 2018. 
Terkait dengan permasalahan tersebut Pasal 8 ayat (2) Kode Etik Notaris menjelaskan bahwa pelanggaran ataupun penerimaan pengaduan yang terlebih dahulu oleh satu dewan kehormatan tidak boleh lagi diperiksa oleh dewan kehormatan lainnya. Ketentuan pasal 8 ayat (2) tersebut dapat diartikan bahwa kemungkinan terjadinya sebuah peristiwa dimana dewan kehormatan notaris wilayah dan daerah sama-sama menemukan temuan terkait pelanggaran kode etik atapun menerima pengaduan secara tertulis dari anggota perkumpulan atau orang lain terkait pelanggaran kode etik bisa saja terjadi, dan apabila itu terjadi maka dewan kehormatan yang terlebih dahulu menerima pengaduan ataupun mendapatkan suatu temuan yang berwenang untuk menyelesaikannya.

Di wilayah Kota Padang ada beberapa pelanggaran yang pernah diadukan maupun menjadi temuan dewan Kehormatan Notaris Daerah Kota Padang. Adapun pelanggaran tersebut adalah sebagai berikut: a). Memberikan ucapan baik suka ataupun duka, atas dasar Notaris bukan personal yang dilarang oleh Kode Etik Notaris, sekedar mengingatkan saja dari Majelis Pengawas Daerah (MPD) agar tidak melanggar lagi; b). Papan nama Notaris tidak sesuai semestinya, misal: dengan ukuran tidak semestinya, pemberian aksesoris pada papan nama berupa lampu hias, dan warna selain hitam dan putih; c). Laporan masyarakat terkait dengan dugaan pada sifat netral, yakni memihak salah satu pihak klien; d). Terdapatnya pengurusan akta yang belum selesai dan memberitahu kepada klien perihal selesainya; e). Membuat akta dengan waktu yang lama; f). Menahan berkas seseorang dengan maksud agar tidak berpindah Notaris; dan, g). Memberikan blanko kosong kepada klien untuk menandatanganinya, dan klien tidak tahu isi akta tersebut. ${ }^{14}$

Terkait upaya pengawasan dan penegakan hukum yang dilakukan oleh Dewan Kehormatan, baik Dewan Kehormatan Daerah INI Kota Padang, pada dasarnya merupakan penegakan kode etik tingkat pertama, namun khusus bagi upaya banding hanya dapat dilakukan oleh Dewan Kehormatan Pusat saja. Hal ini dapat dilihat pada pasal 6 ayat (6) KEN 2016 yang menyatakan bahwa keputusan dewan kehormatan daerah atau dewan kehormatan wilayah berupa pemberhentian sementara atau pemberhentian dengan hormat atau pemberhentian dengan tidak hormat dari keanggotaan perkumpulan dapat diajukan banding ke Dewan Kehormatan Pusat.

Kode etik notaris hasil konggres luar biasa notaris di Bandung tahun 2005, Dewan Kehormatan Daerah diposisikan sebagai pengawas dan

\footnotetext{
14 Wawancara dengan Rahmat Setiadi, tanggal 20 Mei 2018 di kantor Notaris Padang.
} 
penegakan kode etik tingkat pertama. Namun, setelah perubahan kode etik notaris pada tahun 2015 melalui kongres luar biasa INI di Banten, Dewan Kehormatan Daerah Kota Padang tidak lagi diposisikan sebagai pengawas dan penegakan kode etik tingkat pertama saja, tetapi kedudukannya sama dengan Dewan Kehormatan wilayah Sumatera Barat yaitu sama-sama sebagai pengawas dan penegakan kode etik tingkat pertama, dan proses banding hanya dapat dilaksanakan pada Dewan Kehormatan Pusat. Dengan demikian maka proses pengawasan dan penegakan kode etik akan sama, baik pada Dewan Kehormatan Daerah, Dewan Kehormatan Wilayah, maupun Dewan Kehormatan Pusat asalkan pengawasan dan penegakan kode etik dilaksanakan pada tingkat pertama.

Dewan Kehormatan Daerah Kota Padang dalam hal melaksanakan tugasnya melakukan pengawasan dan penegakan kode etik baik atas prakarsa sendiri maupun berdasarkan pengaduan secara tertulis dari anggota perkumpulan atau orang lain. ${ }^{15}$ Disini jelas bahwa terdapat dua sebab dilaksanakannya fungsi pengawasan dan penegakan kode etik oleh dewan kehormatan notaris daerah kota Padang. Prakarsa sendiri yang dimaksudkan disini adalah inisiatif dari Dewan Kehormatan Daerah Ikatan Notaris Indonesia Kota Padang. Inisiatif muncul ketika Daerah Kota Padang perlu melakukan pemantauan terhadap anggota dan apabila dalam prosesnya ditemukan adanya kejanggalan atau dugaan pelanggaran kode etik, maka temuan tersebut akan diteliti lebih lanjut oleh Daerah Kota Padang. Selanjutnya, pengawasan dan penegakan kode etik berdasarkan pengaduan secara tertulis dari anggota perkumpulan atau orang lain. ${ }^{16}$ Pada ketentuan Pasal 8 ayat (1) KEN 2015 jelas disebutkan bahwa pengaduan ini harus dilaksanakan secara tertulis.

Pada intinya pengawasan terhadap notaris yang melakukan pelanggaran kode etik di kota Padang terlebih dahulu harus dipastikan bahwa anggota tersebut benar-benar telah melanggar kode etik notaris, maka proses ini baik temuan Dewan Kehormatan Notaris Daerah Kota Padang maupun laporan dari masyarakat tidak boleh begitu saja dipercaya dan dijadikan pertimbangan untuk menjatuhkan putusan. Namun, harus terlebih dahulu dilakukan upaya-upaya lanjutan yang salah satunya adalah meminta klarifikasi dari si terlapor atau anggota yang diduga melakukan pelanggaran. ${ }^{17}$ Dewan Kehormatan Notaris Daerah Kota Padang setelah menemukan fakta pelanggaran kode etik, selambat-lambatnya dalam waktu 14 (empat belas) hari

\footnotetext{
15 Pasal 8 ayat 1 KEN 2015.

16 Pasal 8 ayat 1 KEN 2015.

17 Pasal 8 ayat 1 KEN 2015.
} 
kerja memanggil secara tertulis anggota yang bersangkutan untuk memastikan terjadinya pelanggaran kode etik oleh anggota perkumpulan dan memberikan kesempatan kepada yang bersangkutan untuk meberikan penjelasan dan pembelaan. Pemanggilan tersebut dikirimkan maksimal 14 (empat belas) hari kerja sebelum tanggal pemeriksaan. ${ }^{18}$

Apabila pada panggilan pertama anggota yang bersangkutan tidak hadir, maka panggilan ini akan diulang maksimal sebanyak 3 kali panggilan secara tertulis dalam rentang waktu maksimal 14 hari kerja setelah panggilan sebelumnya. Jika anggota yang diduga telah melakukan pelanggaran kode etik tersebut tidak juga hadir pada panggilan ketiga, maka Dewan Kehormatan Notaris Daerah Kota Padang tetap melaksanakan sidang etik untuk memeriksa kasus pelanggaran kode etik tersebut berdasarkan temuan ataupun pengaduan tertulis tersebut. ${ }^{19}$

Dalam hal anggota yang bersangkutan hadir dalam sidang etik yang telah dijadwalkan, maka persidangan dapat berlanjut dengan acara pemeriksaan. Acara pemeriksaan harus dihadiri oleh lebih dari setengah jumlah anggota Dewan Kehormatan Notaris Daerah Kota Padang. ${ }^{20}$ Pasal 12 ayat (3) Anggaran Dasar INI menguatkan dugaan tersebut dimana kalimat yang digunakan adalah "Dewan Kehormatan terdiri dari beberapa orang anggota yang dipilih dari Anggota Biasa....". Jadi jelas standar yang digunakan untuk menentukan keabsahan suatu sidang etik adalah persentase anggota yang hadir yaitu setengah atau 50 persen. Akan tetapi Pada kelanjutan Pasal 9 ayat (9) KEN 2015 ketentuan yang mewajibkan kehadiran 50 persen anggota Dewan Kehormatan seakan-akan menjadi sia-sia ketika terdapat pula ketentuan lanjutan yang menyatakan bahwa apabila pada pembukaan sidang jumlah korum tidak tercapai, maka sidang diundur selama 30 menit dan apabila setelah pengunduran waktu tersebut korum juga belum tercapai, maka sidang dianggap sah dan dapat mengambil keputusan yang sah.

Sidang etik Dewan Kehormatan Notaris Daerah Kota Padang dilaksanakan secara tertutup, sedangkan sidang pembacaan putusan terbuka untuk umum. Hal ini ada kaitanya dengan ketentuan Pasal 9 ayat (10) KEN 2015 yang menyatakan bahwa pemeriksaan dan pengambilan keputusan sidang, dewan kehormatan yang memeriksa harus tetap menghormati dan menjunjung tinggi martabat anggota yang bersangkutan, selalu menjaga suasana kekeluargaan dan merahasiakan segala hal yang ditemukannya.

\footnotetext{
18 Pasal 8 ayat 1 KEN 2015.

19 Pasal 8 ayat 1 KEN 2015.

${ }^{20}$ Pasal 8 ayat 1 KEN 2015.
} 
Tujuan tersebut hanya akan tercapai apabila sidang etik yang dilaksanakan oleh Dewan Kehormatan Notaris Daerah Kota Padang berlangsung secara tertutup, akan tetapi untuk tetap menjaga kepercayaan anggota dan masyarakat pembacaan putusan sidang etik tetap disampaikan atau dibacakan dalam sidang yang terbuka.

Sidang etik yang dilaksanakan oleh Dewan Kehormatan Notaris Daerah Kota Padang berjalan maksimal 30 hari kerja. Ada 2 (dua) opsi putusan dalam sidang dewan etik yaitu; menyatakan terbukti melakukan pelanggaran dan putusan tersebut juga diikuti dengan sanksi yang diberikan kepada anggota terkait, sedangkan putusan kedua adalah menyatakan tidak terbukti melakukan pelanggaran yang diiringi dengan upaya pemulihan nama baik dari anggota yang bersangkutan.

Jika terbukti melakukan pelanggaran kode etik, Dewan Kehormatan dapat menjatuhkan sanksi kepada anggota terkait sesuai dengan Pasal 6 ayat (1) KEN 2015 yaitu: a). Teguran; b). Peringatan; c). Pemberhentian sementara dari keanggotaan perkumpulan; d). Pemberhentian dengan terhormat dari keanggotaan perkumpulan; dan, e). Pemberhentian dengan tidak hormat dari keanggotaan perkumpulan.

Keputusan diatas pada dasarnya dapat dijatuhkan oleh Dewan Kehormatan kepada anggota yang bersangkutan atau notaris sesuai dengan tindak pelanggaran kode etik yang dilakukan. Putusan tersebut dibedakan dalam 2 (dua) jenis yaitu putusan yang dapat diajukan banding dan putusan yang tidak dapat diajukan banding. Putusan yang dapat diajukan banding adalah putusan pemberhentian sementara dari keanggotan perkumpulan, putusan pemberhentian dengan terhormat dari keanggotaan perkumpulan dan putusan pemberhentian dengan tidak hormat dari keanggotaan perkumpulan. Sedangkan putusan teguran dan peringatan tidak dapat diajukan banding. ${ }^{21}$

Terkait upaya hukum, KEN 2015 mengatur bahwa seorang anggota terduga melanggar kode etik dapat melakukan banding atas putusan seperti yang telah dijelaskan diatas. Upaya banding ini juga bisa dilakukan terhadap putusan Dewan Kehormatan Pusat yang juga hanya terkait putusan pemberhentian sementara dari keanggotan perkumpulan, putusan pemberhentian dengan terhormat dari keanggotaan perkumpulan dan putusan pemberhentian dengan tidak hormat dari keanggotaan perkumpulan. Banding atas Putusan Dewan Kehormatan Pusat ini diajukan ke kongres INI. ${ }^{22}$

\footnotetext{
${ }^{21}$ Vide Pasal 6 KEN 2015.

22 Vide, Pasal 6 ayat 7 KEN 2015.
} 
Dengan selesainya pemeriksaan dan dibacakannya putusan menjatuhkan sanksi bagi anggota yang melakukan pelanggaran kode etik, maka selanjutnya atas pemeriksaan tersebut dibuatkan berita acara pemeriksaan yang ditandatangani oleh anggota yang bersangkutan dan dewan kehormatan yang memeriksa. Apabila anggota yang bersangkutan tidak bersedia menandatangani berita acara pemeriksaan, maka berita acara pemeriksaan cukup ditandatangani oleh dewan kehormatan yang memeriksa.

Pada dasarnya berita acara adalah sebuah dokumen legalitas untuk dijadikan sebagai bahan bukti suatu transaksi atau kegiatan tertentu. Berita acara pemeriksaan sidang kode etik yang dilaksanakan dan diselenggarakan oleh Dewan Kehormatan Notaris Daerah Kota Padang juga menjadi bentuk pertanggungjawaban dan akuntabilitas kerja Dewan Kehormatan Notaris Daerah Kota Padang kepada organisasi, jadi wajar bila terperiksa tidak mau menandatangani maka berita acara tersebut sah, hal ini saja dengan berita acara pemeriksaan pada perkara pidana di kepolisian dimana tidak ada kewajiban bagi terdakwa untuk menandatangani berita acara tersebut. ${ }^{23}$

Dalam hal anggota yang diduga telah melakukan pelanggaran kode etik dan dalam sidang kode etik tidak terbukti melakukan pelanggaran, maka dewan kehormatan harus melakukan upaya-upaya pemulihan nama baik. Hal ini sangatlah penting mengingat profesi dan jabatan notaris dalam melaksanakan tugas jabatannya memerlukan kepercayaan dari masyarakat maupun dari teman-teman sejawat. Dengan adanya tuduhan ataupun dugaan terhadap seorang notaris, maka dapat menimbulkan rasa ketidakpercayaan masyarakat dan teman-teman se-profesi kepada notaris yang bersangkutan. Hal ini perlu dilakukan untuk menjaga kemaslahatan dari kepentingan bersama, ${ }^{24}$ sehingga tidak menimbulkan permasalahan baru bagi pengguna jasa notaris terkait.

Upaya rehabilitasi yang perlu dilakukan adalah dengan sebuah klarifikasi terhadap dugaan pelanggaran kode etik yang dilakukan oleh anggota itu, di dalam Pasal 9 ayat (7) dan (8) dijelaskan bahwa langkah rehabilitasi nama baik yang wajib dilakukan oleh Dewan Kehormatan Notaris wilayah adalah dengan surat keputusan dewan kehormatan yang memeriksa dan Dewan Kehormatan yang memeriksa wajib mengirimkan surat keputusan tersebut kepada anggota yang diperiksa dengan surat tercatat dan tembusannya kepada pengurus pusat, dewan kehormatan pusat, pengurus

23 Vide, Pasal 6 ayat 7 KEN 2015.

${ }^{24}$ Ahmad Mukri Aji, Urgensi Maslahat Mursalah Dalam Dialektika Pemikiran Hukum Islam, (Bogor: Pustaka Pena Ilahi, 2012), h.66. 
wilayah, dewan kehormatan wilayah, pengurus daerah dan dewan kehormatan daerah.

Setiap kali suatu perkara diselesaikan oleh Pengurus Daerah Kota Padang Ikatan Notaris Indonesia diputuskan dan memiliki kekuatan hukum tetap maka Pengurus Daerah kota Padang Ikatan Notaris Indonesia melaporkan kepada Pengurus Pusat INI agar dapat dicatatkan. Hal ini dilakukan terkait 3 hal, yaitu: Pertama, sebagai pedoman dalam penyelesaian perkara pelanggaran kode etik oleh anggota. Catatan dalam daftar anggota perkumpulan terkait putusan dewan kehormatan yang sudah berkekuatan hukum tetap dapat dijadikan sebagai pedoman dalam menyelesaikan perkara pelanggaran kode etik oleh anggota perkumpulan yang terjadi selanjutnya. Hal ini didasarkan atas logika bahwa Dewan Kehormatan hanya menjabat pada periode tertentu yang pada periode tersebut mengikuti periode kepengurusan Pengurus Wilayah Ikatan Notaris Indonesia. Oleh sebab itu dapat dipastikan bahwa akan lahir generasi-generasi baru Dewan Kehormatan yang belum pernah menjadi anggota dewan Kehormatan sebelumnya, sehingga minim pengalaman dan pengetahuan terkait perkembangan perkara-perkara pelanggaran kode etik. Oleh sebab itu maka generasi baru Dewan Kehormatan INI dapat menjadikan Catatan putusan yang sudah memiliki kekuatan hukum tetap tersebut sebagai acuan, pedoman, ataupun contoh dalam menyelesaikan perkara-perkara pelanggaran kode etik yang mereka tangani.

Dijadikannya catatan dalam daftar anggota perkumpulan terkait putusan dewan kehormatan yang sudah berkekuatan hukum tetap ini dapat dipersamakan dengan yuriprudensial yang menjadi acuan bagi hakim dalam memutuskan suatu perkara yang sama. Dewan Etik juga dapat melihat catatan ini untuk menyelesaikan perkara yang sama dalam hal pelanggaran kode etik. Bahkan bagi Dewan Kehormatan Wilayah Notaris. Pedoman ini sangatlah penting mengingat tidak ada standar baku atau rujukan bagaimana sanksi akan dijatuhkan kepada anggota yang melakukan pelanggran kode etik, sedangkan aturan sendiri hanya menentukan bahwa "sanksi diberikan berdasarkan kualitas dan kuantitas dari pelanggaran."

Kedua, sebagai bahan dalam penyusunan aturan-aturan organisasi serta kode etik. Ikatan Notaris Indonesia sebagai sebuah organisasi yang memiliki anggota juga berwenang dan berkewajiban membuat suatu aturan terkait pencapaian visi dan misi organisasi, selain itu aturan juga penting untuk menciptakan ketertiban di dalam organisisi, begitu juga dengan Ikatan Notaris Indonesia dimana mereka juga diberikan kewenangan itu. Untuk penyusunan aturan-aturan organisasi diperlukan bahan-bahan dan pertimbangan- 
pertimbangan. Dalam hal penyusunan kode etik yang juga merupakan aturan organisasi bahan yang sangat penting adalah pengalaman organisasi itu sendiri. Catatan dalam daftar anggota perkumpulan terkait putusan dewan kehormatan yang sudah berkekuatan hukum tetap adalah informasi mengenai pengalaman organisasi, baik pengalaman anggota maupun pengalaman penyelesaian pelanggaran etik tercatat disana. Dengan adanya catatan ini maka konggres Ikatan Notaris Indonesia sebagai organ yang berwenang menyusun kode etik dapat menganalisanya, sehingga ditemukan kelemahan-kelemahan dalam aturan maupun penyelenggaraan kode etik selama diterapkan.

Dengan diketahuinya kelemahan-kelemahan tersebut, konggres INI dapat menentukan pemecahan permasalahan dan menjawab pertanyaan "bagaimana kode etik yang baik bagi profesi notaris? Dan mengapa pelanggaran kode etik ini masih saja terjadi?" Langkah-langkah yang tepat akan ditemukan dengan cara mempelajari perkara-perkara terdahulu melalui catatan dalam daftar anggota perkumpulan terkait putusan dewan kehormatan yang sudah berkekuatan hukum tetap.

Ketiga, bentuk kontrol kepada anggota yang melakukan pelanggaran kode etik. Catatan dalam daftar anggota perkumpulan terkait putusan dewan kehormatan yang sudah berkekuatan hukum tetap juga dapat dijadikan sarana kontrol personal bagi anggota organisasi. Catatan ini dapat dipandang sebagai rekam jejak seorang anggota/notaris. Rekam jejak (track record) adalah semua hal yang seseorang atau organisasi telah lakukan di masa lalu, yang menunjukkan seberapa baik mereka dalam melakukan pekerjaan, mengatasi masalah, dan lain-lainnya.

Adanya catatan rekam jejak seorang notaris, maka organisasi akan mudah untuk melakukan pengawasan terhadap anggota terkait. Seharusnya notaris yang pernah memiliki catatan pelanggaran kode etik akan berbeda pengawasannya dengan notaris yang belum pernah tersangkut permasalahan kode etik. Oleh sebab itu, Ikatan Notaris Indonesia dapat mengklasifikasikan anggotanya untuk dapat melakukan penanganan yang tepat bagi anggota tersebut. Catatan ini juga dapat menjadi personal kontrol dan social control. Personal kontrol adalah kemampuan seseorang untuk menahan diri agar tidak mencapai kebutuhannya dengan cara melanggar norma-norma yang berlaku di masyarakat. ${ }^{25}$ Sedangkan social control adalah kemampuan kelompok sosial atau lembaga-lembaga di masyarakat melaksanakan norma-norma atau peraturan-

25 Lihat: Nur Rohim Yunus, Restorasi Budaya Hukum Masyarakat Indonesia, (Bogor: Jurisprudence Press, 2012), h.55. 
peraturan menjadi efektif. Catatan ini juga dapat dijadikan proses pendidikan terhadap seseorang yang diajari untuk melakukan pengekangan keinginan (impulse). Di samping itu, faktor internal dan eksternal kontrol harus kuat, juga dengan ketaatan terhadap hukum (law-abiding).

\section{Hubungan Koordinasi antara Pengurus Ikatan Notaris Indonesia Kota Padang dengan Majelis Pengawas Notaris Wilayah terhadap Pelanggaran Kode Etik Notaris}

Pasal 1 angka 2 Peraturan Menteri Hukum dan HAM Nomor 40 Tahun 2015 mengatur bahwa Majelis Pengawas adalah suatu badan yang mempunyai kewenangan dan kewajiban untuk melaksanakan pembinaan dan pengawasan terhadap Notaris. Pembentukan Majelis Pengawas Notaris merupakan sebuah tindakan pengawasan yang dilakukan oleh Negara melalui Menteri Hukum dan Hak Asasi Manusia dan amanah tersebut diteruskan oleh Kementrian Hukum dan Hak Asasi Manusia dengan membentuk Majelis Pengawas Notaris ini. Majelis Pengawas Notaris terdiri atas Majelis Pengawas Daerah, Majelis Pengawas Wilayah dan Majelis Pengawas Pusat.

Dari uraian diatas jelas bahwa maksud dari koordinasi antara Pengurus Daerah Ikatan Notaris Indonesia dengan Kementrian Hukum dan HAM dalam hal pelanggaran kode etik adalah antara Pengurus Wilayah Ikatan Notaris Indonesia dengan Majelis Pengawas Notaris Daerah.

Pengurus Daerah Kota Padang bisa memberikan rekomendasi disertai usulan pemecatan sebagai notaris kepada Menteri Hukum dan Hak Asasi Manusia RI yaitu melalui Majelis Pengawas Notaris. Akan tetapi yang menyampaikan usulan adalah Pengurus Pusat Ikatan Notaris Indonesia, bukan Pengurus daerah. ${ }^{26}$ Setelah mengeluarkan keputusan pemberhentian secara hormat dan secara tidak hormat, pengurus Daerah Kota Padang menyampaikan keputusan tersebut ke Pengurus Pusat Ikatan Notaris Indonesia agar dapat direkomendasikan pemecatan terhadap notaris yang bersangkutan.

Urgensi dari kewenangan dari Pengurus Pusat Ikatan Notaris Indonesia untuk memberikan rekomendasi disertai usulan pemecatan sebagai notaris kepada Majelis Pengawas Notaris adalah bahwa supaya keputusan dari Organisasi Notaris menjadi lebih kuat dan tidak menimbulkan permasalahan hukum baru. Pada Pasal 82 ayat 1 UUJN dijelaskan bahwa "Notaris berhimpun dalam satu wadah Organisasi Notaris." Dan jadi pertanyaan adalah bagaimana

\footnotetext{
${ }^{26}$ Wawancara dengan Chendrawati Gunawan, tanggal 24 Mei 2018 di Hotel Mercure.
} 
ketika Organisasi Notaris yang dalam hal ini adalah Ikatan Notaris Indonesia telah menjatuhkan Keputusan memberhentikan seorang notaris menjadi anggota INI, sedangkan dia masih menjabat sebagai notaris, ini tentu akan menyalahi Pasal 82 UUJN yang menyatakan bahwa notaris berhimpun dalam satu wadah organisasi yaitu Ikatan Notaris Indonesia. Dengan diberikannya kewenangan untuk merekomendasikan dan mengusulkan pemberhentian kepada seorang notaris dari jabatan notarisnya, permasalahan hukum tadi dapat teratasi.

Selain itu, koordinasi antara Majelis Pengawas dengan Pengurus Daerah juga terlihat setelah pemeriksaan notaris yang bersangkutan, dalam hal Majelis Pengawas melalui majelis pemeriksa melakukan pemeriksaan terhadap terduga pelanggar kode etik, hasil pemeriksaan dan salinan putusan Majelis Pemeriksa Wilayah disampaikan kepada Menteri, pelapor, terlapor, Majelis Pengawas Daerah, dan Pengurus Pusat Ikatan Notaris Indonesia, dalam jangka waktu paling lambat 30 (tiga puluh) hari kalender terhitung sejak putusan diucapkan, ${ }^{27}$ sedangkan dalam hal pemeriksaan Pengurus Wilayah Ikatan Notaris Indonesia tidak bisa melakukan intervensi dan sidang pemeriksaan itupun dilangsungkan secara tertutup dan pembacaan putusannya dibacakan pada sidang terbuka.

Bentuk lain dari koordinasi antara Majelis Pengawas Wilayah dengan Pengurus Wilayah Ikatan Notaris Indonesia adalah dengan melakukan rapat koordinasi secara berkala. Rapat Koordinasi yang dilakukan tersebut difasilitasi oleh pihak Kantor Wilayah Kementerian Hukum dan Hak Asasi Manusia dengan dihadiri oleh Majelis Pengawas Daerah. Kemudian diundang juga Pihak Penegak Hukum, Ketua organisasi profesi Ikatan Notaris Indonesia dan beberapa orang Notaris. Koordinasi lain yang dilakukan oleh Majelis Pengawas setiap melakukan pemeriksaan ataupun pemberian sanksi terhadap Notaris maka Dewan Kehormatan selalu memberikan surat tembusan kepada organisasi sebagai pemberitahuan. Dengan adanya koordinasi tersebut, setelah adanya hasil pemeriksaan yang dilakukan oleh Majelis Pengawas Wilayah maka Dewan Kehormatan Daerah bisa memanggil Notaris tersebut dan memberikan nasehat serta pengarahan. ${ }^{28}$

${ }^{27}$ Vide Pasal 27 ayat 5 Permenkumham: M.02.PR.08.10 Tahun 2004 tentang Tata Cara Pengangkatan Anggota, Pemberhentian Anggota, Susunan Organisasi, Tata Kerja, dan Tata Cara Pemeriksaan Majelis Pengawas Notaris.

${ }^{28}$ Vide Pasal 27 ayat 5 Permenkumham: M.02.PR.08.10 Tahun 2004 tentang Tata Cara Pengangkatan Anggota, Pemberhentian Anggota, Susunan Organisasi, Tata Kerja, dan Tata Cara Pemeriksaan Majelis Pengawas Notaris. 


\section{Permasalahan yang timbul terkait Pengawasan terhadap Notaris yang melakukan Pelanggaran Kode Etik oleh Pengurus Ikatan Notaris Indonesia Kota Padang}

Permasalahan hukum yang dimaksudkan disini adalah segala bentuk permasalahan yang bersumber dari hukum/norma hukumnya, sehingga baik secara aturan maupun ekses dari aturan tersebut menjadi suatu kelemahan dalam pelaksanaannya. Permasalahan hukum ini tidak melihat dari aspek faktual, namun hanya secara normatif. Adapun permasalahan hukum yang timbul akibat aturan-aturan yang mengatur tentang pengawasan terhadap notaris yang melakukan pelanggaran kode etik oleh Pengurus Wilayah Ikatan Notaris Indonesia pada dasarnya adalah sebagai berikut:

Pertama, belum memadainya aturan-aturan terkait acara pemeriksaan notaris Oleh Dewan Kehormatan Notaris Ikatan Notaris Indonesia. Dewan Kehormatan Notaris Ikatan Notaris Indonesia merupakan organ dari INI yang keberadaanya tertulis di dalam Anggaran Dasar Ikatan Notaris Indonesia. Namun, jika diinventarisir dalam anggaran dasar tersebut terkait Dewan Kehormatan INI hanya diatur di dalam 4 Pasal. Pertama adalah Pasal 10, Pasal 10 yang hanya menyebutkan organ-organ organisasi Ikatan Notaris Indonesia yang salah satunya adalah Dewan Kehormatan, selanjutnya adalah Pasal 11 diatur terkait pengisian jabatan dewan kehormatan, baik dari dewan kehormatan pusat, dewan kehormatan wilayah, dan dewan kehormatan daerah.

Pada Pasal 12 Anggaran Dasar barulah dijelaskan lebih detail tentang Dewan Kehormatan. Judul bab ini adalah "Dewan Kehormatan", dengan judul yang demikian harapannya pengaturan tentang Dewan Kehormatan akan lebih rinci dan memberikan lebih banyak informasi, minimal tentang penjelasan kemana aturan-aturan lebih rinci terkait Pelaksanaan tugas Dewan Kehormatan dalam mengawasi dan membina anggota perkumpulan, akan tetapi penjelasan tersebut tidak ditemukan. Hal ini juga dimaklumi karena memang Anggaran Dasar adalah Garis Besar Arah Organisasi.

Selanjutnya, Pasal 13 dalam Bab-Bab Penegakan Kode Etik juga tidak mengarahkan kemana Dewan Kehormatan ini akan berpedoman dalam beracara, sedangkan yang dinyatakan dalam Pasal 13 Anggaran Dasar tersebut adalah: a). Untuk menjaga kehormatan dan keluhuran martabat jabatan Notaris, Perkumpulan mempunyai Kode Etik Notaris yang ditetapkan oleh Konggres dan merupakan kaidah moral yang wajib ditaati oleh setiap anggota 
Perkumpulan; b). Dewan Kehormatan melakukan upaya-upaya untuk menegakkan Kode Etik Notaris; c). Dewan Kehormatan dapat bekerjasama dengan Pengurus Perkumpulan dan berkoordinasi dengan Majelis Pengawas dan/atau Majelis Kehormatan Notaris untuk melakukan upaya penegakan Kode Etik Notaris; d). Pengaturan mengenai penegakan kode etik ini dapat kita temui di dalam Kode Etik Notaris pada Pasal 6 sampai Pasal 14 Kode Etik Notaris. Pada dasarnya hal yang diatur di dalam Pasal 6 sampai Pasal 14 tersebut adalah sebagai berikut: 1). Jenis hukuman; 2). Kewenangan Dewan Kehormatan Daerah, Dewan Kehormatan Wilayah, dan Dewan Kehormatan Pusat; 3). Kedudukan Dewan Kehormatan; 4). Upaya banding; 5). Terkait putusan dan berita acara pemeriksaan.

Pengaturan mengenai sidang etik oleh Dewan Pengawas Notaris ini terlihat belumlah memadai karena tidak menyangkut pemeriksaan etik secara mendalam. Pada kode etik tersebut tidak diatur bagaimana proses pemeriksaan, misalnya alat bukti yang digunakan, menghadirkan saksi-saksi, dan banyak lainnya terkait acara sidang etik tersebut. Hanya salah satu petunjuk adalah prinsip kekeluargaan dalam pemeriksaan notaris ini mengindikasikan bahwa proses pemeriksaan dapat dilakukan dengan cara-cara yang kasuistis tergantung kasusnya dimana yang diutamakan adalah prinsipprinsip kekeluargaan. Hal demikian mengurangi kepastian hukum dalam penegakan kode etik notaris.

Kedua, tidak ada ketentuan yang mengatur perpanjangan sidang etik oleh Dewan Kehormatan Notaris Ikatan Notaris Indonesia. Dalam hal penegakan kode etik, hasil akhir adalah suatu yang penting, keputusan sidang etik oleh dewan kehormatan notaris haruslah keputusan berdasarkan kebenaran, sehingga aturan-aturan yang akan melemahkan upaya pencarian kebenaran tersebut wajib dipandang sebagai masalah. Salah satu masalah yang patut menjadi sorotan adalah terkait jangka waktu sidang etik tersebut. Pada Pasal 9 ayat (6) Kode Etik Notaris dijelaskan bahwa:

\footnotetext{
“Dewan Kehormatan yang memeriksa selambat-lambatnya 30 hari kerja setelah tanggal sidang terakhir diwajibkan untuk mengambil keputusan atas hasil pemeriksaan tersebut sekaligus menentukan sanksi terhadap pelanggarnya apabila terbukti ada pelanggaran sebagaimana diatur di dalam Pasal 6 kode etik.
}

Ketentuan tersebut berkaitan dengan pemeriksaan kode etik pada dewan kehormatan hanya berjalan 30 (tiga puluh) hari, setelah itu Dewan Kehormatan wajib menjatuhkan putusan dan memberikan sanksi apabila terbukti ada pelanggaran. Permasalahannya adalah bagaimana jika dalam 30 
hari pemeriksaan belum diselesaikan, sehingga Dewan Kehormatan belum bisa mengeluarkan keputusan, ketentuan ini juga tidak di back-up oleh ketentuan yang dapat memperpanjang waktu pemeriksaan, sehingga mau tidak mau dewan kehormatan wajib mengeluarkan keputusan dalam jangka waktu tersebut. Disisi lain Dewan Kehormatan tidak diperbolehkan untuk mengeluarkan putusan yang mereka tidak yakin dengan kebenaran putusan tersebut karena pemeriksaan yang belum selesai.

Pada dasarnya putusan Dewan Kehormatan Ikatan Notaris Indonesia dalam memutus bisa mengeluarkan keputusan terbukti melanggar kode etik dan dikenakan sanksi sesuai dengan Pasal 6 ayat 1 KEN 2015. Putusan lain adalah tidak terbukti melanggar kode etik, sehingga nama baik anggota/notaris yang bersangkutan haruslah dipulihkan. Jika pada waktu 30 hari pemeriksaan belum sepenuhnya selesai dan Dewan Kehormatan memaksakan keluarnya putusan dan menghukum anggota tersebut dengan sanksi diberhentikan sementara, diberhentikan dengan hormat maupun diberhentikan dengan tidak hormat, maka anggota tersebut dapat melakukan upaya banding jika mereka merasa dirugikan dengan keluarnya putusan dewan kehormatan, akan tetapi jika putusan yang dikeluarkan oleh Dewan Kehormatan adalah teguran dan peringatan yang tidak bisa diajukan banding, maka anggota tersebut hanya dapat menerima putusan dan yang lebih berbahaya lagi bahwa putusan INI secara tidak langsung akan berpengaruh kepada nama baik dari notaris tersebut. Oleh sebab itu, ketentuan mengenai perpanjangan masa pemeriksaan menjadi hal yang perlu diatur agar pemeriksaan oleh Dewan Kehormatan dapat benar-benar tuntas.

Ketiga, tidak adanya kewenangan Dewan Kehormatan Notaris Ikatan Notaris Indonesia untuk memberhentikan notaris dari jabatannya. Di dalam Pasal 82 UUJN dijelaskan bahwa:

(1) Notaris berhimpun dalam satu wadah Organisasi Notaris.

(2) Wadah Organisasi Notaris sebagaimana dimaksud pada ayat (1) adalah Ikatan Notaris Indonesia.

(3) Organisasi Notaris sebagaimana dimaksud pada ayat (1) merupakan satu-satunya wadah profesi Notaris yang bebas dan mandiri yang dibentuk dengan maksud dan tujuan untuk meningkatkan kualitas profesi Notaris.

(4) Ketentuan mengenai tujuan, tugas, wewenang, tata kerja, dan susunan organisasi ditetapkan dalam Anggaran Dasar dan Anggaran Rumah Tangga Organisasi Notaris.

(5) Ketentuan mengenai penetapan, pembinaan, dan pengawasan Organisasi Notaris diatur dengan Peraturan Menteri." 
Pada Pasal tersebut jelas dikatakan bahwa Notaris tergabung di dalam suatu organisasi notaris, dan organisasi notaris yang dimaksud adalah Ikatan Notaris Indonesia (INI), bahkan ini dinyatakan sebagai satu-satunya organisasi notaris yang diakui. Ketentuan Pasal 82 tersebut akan menjadi suatu permasalahan ketika notaris yang melanggar kode etik dijatuhi sanksi diberhentikan dengan hormat maupun tidak hormat dari organisasi Dewan Kehormatan Ikatan Notaris Indonesia. Kemudian yang menjadi pertanyaan bolehkah seorang notaris tidak menjadi anggota organisasi notaris? Jika boleh tentu harus ada aturan hukum yang melandasinya atau untuk menjelaskan lebih lanjut Pasal 82 ayat (1) di atas.

Pada dasarnya Dewan Kehormatan diberikan ruang untuk menutupi permasalahan hukum tersebut. Hal ini dapat dilihat dalam Pasal 6 ayat (8) dan Pasal 14. Di dalam Pasal 6 ayat (8) dijelaskan bahwa Dewan kehormatan pusat berwenang pula untuk memberikan rekomendasi disertai usulan pemecatan sebagai notaris kepada Menteri Hukum dan Hak Asasi Manusia RI, sedangkan Pasal 14 menyatakan bahwa "Pengenaan sanksi pemberhentian sementara atau pemberhentian dengan hormat atau pemberhentian dengan tidak hormat dari keanggotaan perkumpulan terhadap pelanggaran sebagaimana dimaksud Pasal 6 diatas wajib diberitahukan oleh pengurus pusat kepada majelis pengawas daerah dan tembusannya disampaikan kepada menteri hukum dan hak asasi manusia RI."

Kedua Pasal ini saling berkaitan, Pasal 14 merupakan bentuk koordinasi antara Ikatan Notaris Indonesia dengan Kementrian Hukum dan HAM, dan di dalam koordinasi tersebut Dewan Kehormatan Notaris bisa memberikan rekomendasi dan usulan kepada Kementrian Hukum dan HAM terkait pemecatan notaris, dalam rekomendasi dan usulah ini Dewan kehormatan dapat memberikan pertimbangan-pertimbangan kepada Kementrian Hukum dan HAM mengenai mengapa pemecatan terhadap notaris yang bersangkutan perlu dilakukan.

Tentu Kementrian Hukum dan HAM tidak hanya akan mengabulkan rekomendasi tersebut, dewan kehormatan melalui Majelis Pengawas dan Majelis Pemeriksa juga memiliki mekanisme pemeriksaan, sehingga sampai pada kesimpulan menjatuhkan putusan pada seorang notaris yang direkomendasikan atau diusulkan dipecat. Akan tetapi jika majelis pengawas dan dewan pemeriksa tidak mengabulkan rekomendasi dari dewan kehormatan notaris, maka hal ini akan menjadi masalah karena kedudukan notaris terkait selanjutnya yang tidak lagi tergabung di dalam organisasi notaris. 
Sementara dalam hal sanksi pelanggaran kode etik yang "cuma" diberhentikan sebagai anggota organisasi notaris, yang bersangkutan masih bisa menjalankan tugasnya karena berhak memberhentikan notaris adalah Menteri. Dengan sanksi ini, oknum notaris yang "kebablasan" justru bersorak jika diberhentikan keanggotaannya dari organisasi karena organisasi tidak mengawasi lagi. Untuk itu organisasi kemudian menyerahkan putusannya ke pemerintah agar ditindaklanjuti. ${ }^{29}$ Sebagai catatan, di dalam pasal 13 UUJN dikatakan bahwa "Notaris diberhentikan dengan tidak hormat oleh Menteri karena dijatuhi pidana penjara berdasarkan putusan pengadilan yang telah memperoleh kekuatan hukum tetap karena melakukan tindak pidana yang diancam dengan pidana penjara 5 (lima) tahun atau lebih." Oleh karena itu, adanya ketentuan Pasal 13 tersebut Kementrian Hukum dan HAM hanya bisa menjatuhkan putusan pemberhentian dengan hormat terhadap seorang notaris jika terkait pelanggaran kode etik.

Keempat, pemulihan nama baik hanya dilakukan dengan SK kepengurus dan Dewan kehormatan Ikatan Notaris Indonesia. Nama baik merupakan aspek yang penting baik untuk diri sendiri maupun bagi orang lain, ada pepatah mengatakan "gajah mati meninggalkan gading, harimau mati meninggalkan belang, manusia mati meninggalkan nama." Maksud dari pepatah tersebut adalah bahwa hal yang akan ditinggalkan ketika tiada adalah hal yang begitu penting penanda diri kita, sedang pada manusia adalah nama, dan nama yang dimaksudkan disini tidak hanya nama dalam artian sebenarnya. Namun, juga kenangan-kenangan seseorang tentang diri kita, bisa saja itu kenangan baik maupun kenangan buruk.

Seseorang yang diduga melanggar suatu aturan, maka pada dirinya melekat cap sebagai orang yang "tidak taat", sedangkan orang yang melanggar etika dicap sebagai "tidak beretika", anggapan-anggapan tersebut akan menjadi citra negatf bagi diri seseorang. Anggapan-anggapan negatif ini tentu akan berpengaruh kepada sikap seseorang, misalnya pengusaha yang dianggap curang akan dijauhi pelanggan. Hal ini juga berlaku pada profesi-profesi tertentu, termasuk juga pemangku jabatan notaris.

Dalam hal seorang notaris diduga telah melakukan pelanggaran kode etik, baik atas laporan teman sejawat maupun laporan masyarakat, maka pandangan orang-orang yang mengetahui dugaan tersebut akan berubah, minimal diantara keraguan terhadap benar atau tidaknya notaris yang

${ }^{29}$ Winanto Wiryomartani, notaris senior yang juga anggota Majelis Pengawas Pusat Notaris, http://medianotaris.com/, diakses pada 2 Mei 2018. 
bersangkutan telah melanggar kode etik. Pandangan ini akan berbuntut panjang sampai dengan pada tingkat hilangnya kepercayaan masyarakat kepada notaris yang bersangkutan.

Untuk mengantisipasi keadaan diatas, maka ditetapkanlah di dalam Pasal 9 ayat (7) dan (8) bahwa apabila anggota yang bersangkutan tidak terbukti melakukan pelanggaran, maka anggota tersebut dipulihkan namanya dengan surat keputusan dewan kehormatan yang memeriksa. Dewan kehormatan yang memeriksa wajib mengirimkan surat keputusan tersebut kepada anggota yang diperiksa dengan surat tercatat dan tembusanya kepada pengurus pusat, dewan kehormatan pusat, pengurus wilayah, dewan kehormatan wilayah, pengurus daerah dan dewan kehormatan daerah.

Hal tersebut merupakan upaya pengembalian nama baik seorang notaris ketika tidak terbukti melakukan pelanggaran kode etik, namun upaya tersebut belumlah cukup, mengingat berita tentang pelanggaran kode etik belum tentu tersebar hanya di kalangan notaris dan organisasi, bahkan berita seperti ini berpeluang tersebar keluar lingkungan notaris dan organisasi, sehingga upaya pengembalian nama baik seprti di atas masih belum cukup.

Solusi yang tepat untuk permasalahan terkait pelanggaran kode etik, maka Dewan Kehormatan yang memeriksa harus menyebarluarkan keputusan atas pemeriksaan tersebut kepada masyarakat. Dengan demikian notaris yang bersangkutan bisa mendapatkan kepercayaan lagi dari masyarakat.

\section{Kesimpulan}

Pengawasan dan Penegakan Kode Etik terhadap Notaris yang melakukan pelanggaran Kode Etik oleh Pengurus Ikatan Notaris Indonesia kota Padang dilaksanakan oleh Dewan Kehormatan Daerah. Pengawasan dan penegakan kode etik dilaksanakan secara bertingkat, apabila terduga pelanggaran kode etik tidak puas dengan keputusan dewan kehormatan daerah, maupun wilayah maka dapat mengajukan banding terhadap Dewan Kehormatan Pusat, dan jika belum terpuaskan dengan putusan Dewan Kehormatan Pusat, maka bisa diajukan banding ke Konggres. Atas keputusan yang berkekuatan hukum tetap, maka pengurus pusat wajib mencatat dalam buku daftar anggota perkumpulan.

Hubungan Koordinasi antara Pengurus Ikatan Notaris Indonesia Kota Padang dengan Majelis Pengawas Notaris daerah terhadap Pelanggaran Kode Etik Notaris terbangun melalui rapat koordinasi secara berkala. Koordinasi 
setiap melakukan pemeriksaan ataupun pemberian sanksi terhadap Notaris dan koordinasi terkait pemberian usulan dan rekomendasi yang menjadi kewenangan Dewan Kehormatan Pusat.

Permasalahan Hukum yang timbul terkait Pengawasan terhadap Notaris yang melakukan Pelanggaran Kode Etik oleh Pengurus Ikatan Notaris Indonesia Kota Padang yaitu belum memadainya aturan-aturan terkait acara pemeriksaan notaris oleh Dewan Kehormatan Notaris Ikatan Notaris Indonesia. Tidak ada ketentuan yang mengatur perpanjangan sidang etik oleh Dewan Kehormatan Notaris Ikatan Notaris Indonesia dan tidak adanya kewenangan Dewan Kehormatan Notaris Ikatan Notaris Indonesia untuk memberhentikan notaris dari jabatannya, dan pemulihan nama baik hanya dilakukan dengan SK Pengurus Daerah dan Dewan kehormatan Ikatan Notaris Indonesia.

\section{Daftar Pustaka}

Aji, Ahmad Mukri. Urgensi Maslahat Mursalah Dalam Dialektika Pemikiran Hukum Islam, Bogor: Pustaka Pena Ilahi, 2012.

Asshiddiqie, Jimly Peradilan Etik Dan Etika Konstitusi, , Jakarta: Sinar grafika, 2014.

Fadli, Zul, Membedah Kode Etik Baru, Majalah Renvoi, 3 Januari 2016, Jakarta 2016.

http://www.hukumonline.com/berita/baca/lt578f0c854d540/belajar-dari-kasusiain-ib--notaris-diminta-jaga-profesionalisme, diakses pada 9 April 2018

Ignatius Ridwan Widyadharma, Etika Profesi Hukum, Badan Penerbit Universitas Diponegoro, Semarang, 1996.

Moenir, Manajemen Pelayanan Umum di Indonesia, PT. Bumi Aksara, Jakarta, 2002.

Pasal 82 UUJN

Pengurus Pusat Ikatan Notaris Indonesia, Jati Diri Notaris Indonesia Dulu.

Sekarang dan Di Masa Datang, Jakarta: Gramedia Pustaka, 2008.

Wawancara dengan Chendrawati Gunawan, tanggal 24 Mei 2018 di Hotel Mercure.

Wawancara dengan Rahmat Setiadi, tanggal 20 Mei 2018 di kantor Notaris Padang 
Wiryomartani, Winanto, notaris senior yang juga anggota Majelis Pengawas Pusat Notaris, http://medianotaris.com/, diakses pada 2 Mei 2018.

Yunus, Nur Rohim. Restorasi Budaya Hukum Masyarakat Indonesia, Bogor: Jurisprudence Press, 2012. 


\section{JURNAL}

\section{CITA HUXUM INDONESIAN LAW JOURNAL}

\section{TECHNICAL GUIDANCE FOR AUTHORS OF CITA HUKUM JOURNAL}

1. Article must be original, not plagiarism, unpublished, and not under review for possible publication in other journals.

2. Article should be concept, research-based, and toughts;

3. Article should be written in Bahasa Indonesia or English

4. Article must contain of Law Science

5. Writing Guidance as follows:

a. Title is written by Capital maximum 12 words in the center

b. Name of authors are written completely, no degree, institutional affiliation, address, and email.

c. Abstract is written in Bahasa Indonesia or English maximum 120 words.

d. Systematycs of article:

1) Title

2) Name of authors (no title), name of affiliation, email

3) Abstract

4) Keywords, between 2-5 words

5) Introduction

6) Sub title (if need it)

7) Closing

8) Bibliography (The bibliography list contains all references in text originating from sources that are relevant and at least up to date (last 10 years).

e. Paper Sizes are $17,5 \times 24 \mathrm{~cm}$, up $2,5 \mathrm{~cm}$, down, $2,5 \mathrm{~cm}$, right $2,5 \mathrm{~cm}$, and left $2,5 \mathrm{~cm}$

f. Length of article is between $18-20$ pages with 1.0 line spacing , Palatyno Fond Style with 10 size.

g. Rule of citation. Direct citation if word is more than 4 lines separated from the text with 1.0 spacing with 9 font. However if citation less than 4 lines, it should be integrated in the text with double apostrof both in the first and in the end. Every citation is given number. Citation system is footnote not body note or endnote and use turabia system. Every article, book, and other source should be citated on the reference.

h. Citation for Quran and Hadist. For verse citation contains name of surah, number of surah and number of verse example: (Qs. Al Mumin [40]: 43). For Hadis citation, mention name of Perawi/Author, example (H. R al-Bukhari and Muslim) and printed hadist version. Hadist must be from standar hadist books (Kutub at-Tisah).

i. Footnote is written by Palatino Linotype style, size 8 , for any sources as follows:

1) Book: Author's name (without title), title of book (place publised: publisher, year of published), Version, Volume, Batch, Page. Example: Soerjono Soekanto, Pokok-Pokok Sosiologi Hukum, (Jakarta: Rajawali Press, 1986), p. 10. 
2) Translated Book. Example: Roscoe Pound, Pengantar Filsafat Hukum: Book III, translated by Moh. Radjab, (Jakarta: Bharata, 1963), p.15.

3) Journal, example: Nur Rohim Yunus, "Kontroversi Pembentukan Perppu No. 1 Tahun 2013 tentang Mahkamah Konstitusi Dalam Ranah Kegentingan Yang Memaksa", Jurnal Cita Hukum, Volume 1 Number 1 (2014), p.157.

4) Article as a part of book (antology). Contoh: Hikmahanto Juwana, "Penegakan Hukum dalam Kajian Law and Development: Problem dan Fundamen bagi Solusi Indonesia", in Muhammad Tahir Azhary, Beberapa Aspek Hukum Tata Negara, Hukum Pidana, dan Hukum Islam, (Jakarta: Kencana Prenada Media Group, 2012), p.127.

5) Article from internet, example: Ahmad Tholabie Kharlie, "Problem Yuridis RUU Syariah" in http://ahmadtholabi.com/2008/03/03problem-yuridis-ruu-syariah, downloaded on March 20, 2012.

6) Article from magazine, example: Susilaningtias, "Potret Hukum Adat pada Masa Kolonial", in Forum Keadilan, No. 17, August 20, 2017.

7) Article in Seminar, example: Jimly Asshidiqqie, "Kedudukan Mahkamah Konstitusi dalam Struktur Ketatanegaraan Indonesia", paper presented on public lecture at faculty of law Universty Sebelas Maret, Surakarta on March 2, 2014.

j. Bibliography. Bibliography is written alphabeticaly, last author's name is in the first of name, example:

1) Book: Soekanto, Soerjono, Pokok-Pokok Sosiologi Hukum, Jakarta: Rajawali Press, 1986.

2) Translated Book. Example: Pound, Roscoe, Pengantar Filsafat Hukum: Book III, translated by Moh. Radjab, Jakarta: Bharata, 1963.

3) Journal, example: Rohim, Nur, "Kontroversi Pembentukan Perppu No. 1 Tahun 2013 tentang mahkamah konstitusi dalam ranah kegentingan yang memaksa", Jurnal Cita Hukum, Volume 1 Number 1 (2014).

4) Article as a part of book (antology). example: Juwana, Hikmahanto, "Penegakan Hukum dalam Kajian Law and Development: Problem dan Fundamen bagi Solusi Indonesia", in Muhammad Tahir Azhary, Beberapa Aspek Hukum Tata Negara, Hukum Pidana, dan Hukum Islam, Jakarta: Kencana Prenada Media Group, 2012.

5) Article from internet, example: Kharlie, Ahmad Tholabie, "Problem Yuridis RUU Syariah" in http://ahmadtholabi.com/2008/03/03problem-yuridis-ruu-syariah, downloaded on March 20, 2012.

6) Article from magazine, example: Susilaningtias, "Potret Hukum Adat pada Masa Kolonial", in Forum Keadilan, No. 17, August 20, 2016.

7) Article in Seminar, example: Asshidiqqie, Jimly, "Kedudukan Mahkamah Konstitusi dalam Struktur Ketatanegaraan Indonesia", paper presented on public lecture at faculty of law Universty Sebelas Maret, Surakarta on March 2, 2014.

k. Closing, article is closed by conclusion;

I. Short biography: author's biography contains full name, title, institution, education and other academic experts.

6. Every article that doesnt fufill all requirements to this guidance will give it back to the author for revision.

7. Article must be submitted to editors at least 3 months before publishing (June and December) with uploading via OJS to http://journal.uinjkt.ac.id/index.php/citahukum or e-mail to jurnal.citahukum@uinjkt.ac.id.] 


\section{PEDOMAN TEKNIS PENULISAN BERKALA ILMIAH JURNAL CITA HUKUM}

1. Artikel adalah benar-benar karya asli penulis, tidak mengandung unsur plagiasi, dan belum pernah dipublikasikan dan/atau sedang dalam proses publikasi pada media lain yang dinyatakan dengan surat pernyataan yang ditandatangani di atas meterai Rp 6000;

2. Naskah dapat berupa konseptual, resume hasil penelitian, atau pemikiran tokoh;

3. Naskah dapat berbahasa Indonesia atau Inggris;

4. Naskah harus memuat informasi keilmuan dalam ranah ilmu hukum Positif;

5. Aturan penulisan adalah sebagai berikut:

a. Judul. Ditulis dengan huruf kapital, maksimum 12 kata diposisikan di tengah (centered);

b. Nama penulis. Ditulis utuh, tanpa gelar, disertai afiliasi kelembagaan dengan alamat lengkap, dan alamat e-mail;

c. Abstrak. Ditulis dalam bahasa Indonesia dan bahasa Inggris masing-masing hanya 120 kata saja;

d. Sistematika penulisan naskah adalah sebagai berikut:

1) Judul;

2) Nama penulis (tanpa gelar akademik), nama dan alamat afiliasi penulis, dan e-mail;

3) Abstrak;

4) Kata-kata kunci, antara 2-5 konsep yang mencerminkan substansi artikel;

5) Pendahuluan;

6) Sub judul (sesuai dengan keperluan pembahasan);

7) Penutup; dan

8) Pustaka Acuan (hanya memuat sumber-sumber yang dirujuk dan sedapat mungkin terbitan 10 tahun terakhir).

e. Ukuran kertas yang digunakan ukuran $17,5 \times 24 \mathrm{~cm}$, margin: atas $2,5 \mathrm{~cm}$, bawah $2.5 \mathrm{~cm}$, kiri 2,5 $\mathrm{cm}$, dan kanan 2,5 cm;

f. Panjang Naskah antara 18 s.d. 20 halaman, spasi 1, huruf Palatino Linotype, ukuran 10;

g. Pengutipan kalimat. Kutipan kalimat ditulis secara langsung apabila lebih dari empat baris dipisahkan dari teks dengan jarak satu spasi dengan ukuran huruf 9 point. Sedangkan kutipan kurang dari empat baris diintegrasikan dalam teks, dengan tanda apostrof ganda di awal dan di akhir kutipan. Setiap kutipan diberi nomor. Sistem pengutipan adalah footnote (bukan bodynote atau endnote). Penulisan footnote menggunakan sistem turabian. Setiap artikel, buku, dan sumber lainnya yang dikutip harus tercantum dalam pustaka acuan;

$h$. Pengutipan Ayat Alquran dan Hadis. Ayat yang dikutip menyertakan keterangan ayat dalam kurung, dengan menyebut nama surah, nomor surah, dan nomor ayat, seperti (Q.S. al-Mu'min [40]: 43). Pengutipan Hadis menyebutkan nama perawi (H.r. al-Bukhārī dan Muslim) ditambah referensi versi cetak kitab Hadis yang dikutip. Hadis harus dikutip dari kitab-kitab Hadis standar (Kutub al-Tis'ah);

i. Cara pembuatan footnote. Footnote ditulis dengan font Palatino Linotype, Size 8, untuk pelbagai sumber, antara lain:

1) Buku: nama utuh penulis (tanpa gelar), judul buku (tempat terbit: penerbit, tahun terbit), cetakan, volume, juz, halaman. Contoh: Soerjono Soekanto, Pokok-pokok Sosiologi Hukum, (Jakarta: Rajawali Pers, 1986), h. 10.

2) Buku terjemahan, contoh: Roscoe Pound, Pengantar Filsafat Hukum: Buku III, diterjemahakan oleh Moh. Radjab, (Jakarta: Bharata, 1963), h. 15;

1) Jurnal, contoh: Nur Rohim Yunus, "Kontroversi Pembentukan Perppu No. 1 Tahun 2013 tentang mahkamah konstitusi dalam ranah kegentingan yang memaksa", dalam Jurnal Cita Hukum, Vol. I, No. 1, Juni 2014, h. 157. 
2) Artikel sebagai bagian dari buku (antologi), contoh: Hikmahanto Juwana, "Penegakan Hukum dalam Kajian Law and Development: Problem dan Fundamen bagi Solusi Indonesia", dalam Muhammad Tahir Azhary, Beberapa Aspek Hukum Tata Negara, Hukum Pidana, dan Hukum Islam, (Jakarta: Kencana Prenada Media Gorup, 2012), h.127.

3) Artikel dari internet, contoh: Ahmad Tholabi Kharlie, "Problem Yuridis RUU Syariah" dalam http://ahmadtholabi.com/2008/03/03/problem-yuridis-ruu-syariah, diunduh pada 20 Maret 2012.

4) Artikel dari majalah, contoh: Susilaningtias, "Potret Hukum Adat pada Masa Kolonial", dalam Forum Keadilan, No. 17, 20 Agustus 2006.

5) Makalah dalam seminar, contoh: Jimly Asshiddiqie, "Kedudukan Mahkamah Konstitusi dalam Struktur Ketatanegaraan Indonesia", Makalah disampaikan dalam Kuliah Umum Fakultas Hukum Universitas Sebelas Maret, Surakarta, pada 2 Maret 2004.

j. Pustaka Acuan: daftar pustaka acuan ditulis sesuai urutan abjad, nama akhir penulis diletakkan di depan. Contoh:

1) Buku, contoh: Soekanto, Soerjono, Pokok-pokok Sosiologi Hukum, Jakarta: Rajawali Pers, 1986.

2) Buku terjemahan, contoh: Pound, Roscoe, Pengantar Filsafat Hukum: Buku III, diterjemahakan oleh Moh. Radjab, Jakarta: Bharata, 1963.

3) Jurnal, contoh: Rohim, Nur, "Kontroversi Pembentukan Perppu No. 1 Tahun 2013 tentang mahkamah konstitusi dalam ranah kegentingan yang memaksa", dalam Jurnal Cita Hukum, Vol. I, No. 1, Juni 2014.

4) Artikel sebagai bagian dari buku, contoh: Juwana, Hikmahanto, "Penegakan Hukum dalam Kajian Law and Development: Problem dan Fundamen bagi Solusi Indonesia", dalam Muhammad Tahir Azhary, Beberapa Aspek Hukum Tata Negara, Hukum Pidana, dan Hukum Islam, Jakarta: Kencana Prenada Media Gorup, 2012.

5) Artikel yang dikutip dari internet, contoh: Kharlie, Ahmad Tholabi, "Problem Yuridis RUU Syariah" dalam http://ahmadtholabi.com/2008/03/03/problem-yuridis-ruu-syariah, diunduh pada 20 Maret 2012.

6) Majalah, contoh: Susilaningtias, "Potret Hukum Adat pada Masa Kolonial", dalam Forum Keadilan, No. 17, 20 Agustus 2006.

7) Makalah dalam seminar, contoh: Asshiddiqie, Jimly, "Kedudukan Mahkamah Konstitusi dalam Struktur Ketatanegaraan Indonesia", Makalah disampaikan dalam Kuliah Umum Fakultas Hukum Universitas Sebelas Maret, Surakarta, pada 2 Maret 2004.

k. Penutup: artikel ditutup dengan kesimpulan;

I. Biografi singkat: biografi penulis mengandung unsur nama (lengkap dengan gelar akademik), tempat tugas, riwayat pendidikan formal (S1, S2, S3), dan bidang keahlian akademik;

6. Setiap naskah yang tidak mengindahkan pedoman penulisan ini akan dikembalikan kepada penulisnya untuk diperbaiki.

7. Naskah sudah diserahkan kepada penyunting, selambat-lambatnya tiga bulan sebelum waktu penerbitan (Juni dan Desember) dengan mengupload langsung via OJS ke alamat: http://journal.uinjkt.ac.id/index.php/citahukum atau via e-mail ke: jurnal.citahukum@uinjkt.ac.id.[] 
in Collaboration with :

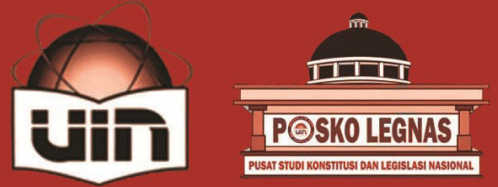

Indexed by :
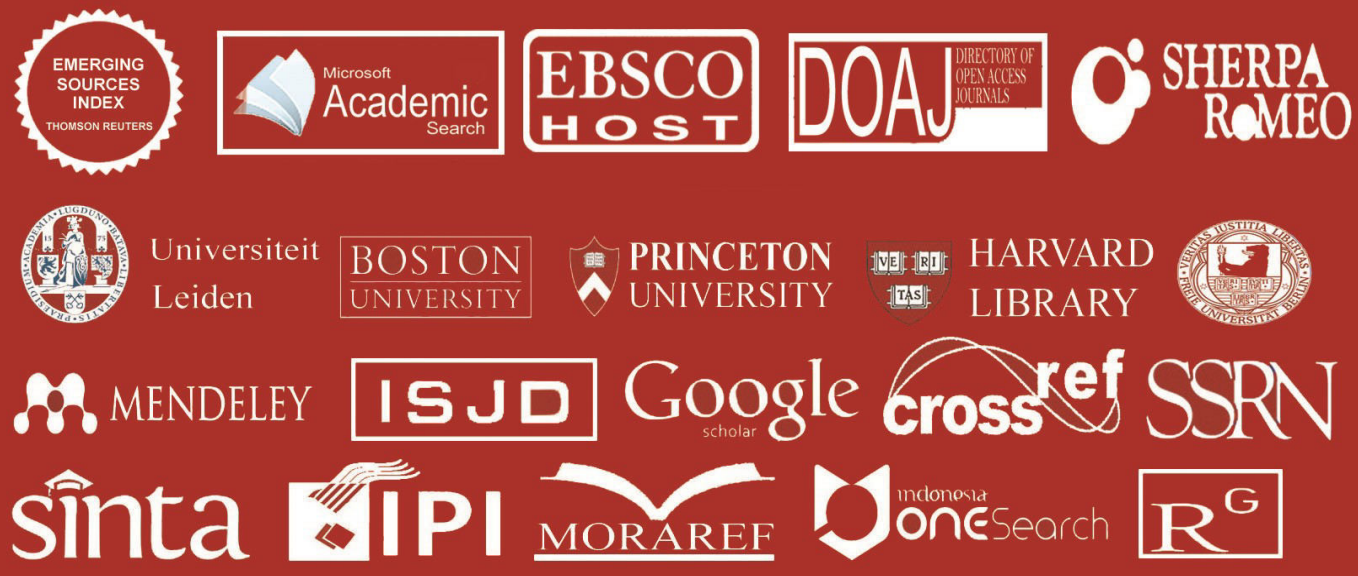

JURNAL CITA HUKUM is a peer-reviewed journal on Indonesian Law Studies published biannual (June \& December) by Faculty of Sharia and Law Universitas Islam Negeri Syarif Hidayatullah Jakarta in cooperation with Center for the Study of Constitution and National Legislation (POSKO-LEGNAS). JURNAL CITA HUKUM aims primarily to facilitate scholarly and professional discussions over current developments on legal issues in Indonesia as well as to publish innovative legal researches concerning Indonesian laws.
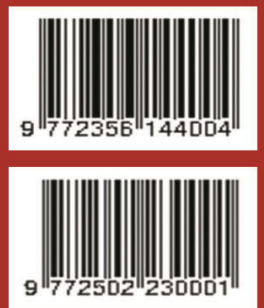